\title{
The Effect of Competency, Vocational, Training and Work Discpline on The Performance of PT Indomika Utama
}

\author{
Agtovia Frimayasa ${ }^{1}$, Windayanti ${ }^{2}$, Didin Hikmah Perkasa ${ }^{3}$ \\ \{Agtovia.frimayasa@undira.ac.id ${ }^{1}$, windayanti@gmail.com² ${ }^{2}$,didin.hikmah.perkasa@undira.ac.id ${ }^{2}$ \} \\ Universitas Dian Nusantara, Jakarta, Indonesia ${ }^{1}$, Universitas Dian Nusantara, Jakarta, Indonesia ${ }^{2}$, Universitas \\ Dian Nusantara, Jakarta, Indonesia ${ }^{3}$
}

\begin{abstract}
The main research objective of this study was to measure the influence of competence, job training, and work discipline on employee performance at PT. Indomika Utama uses a quantitative descriptive approach. The data in the study were obtained from 62 respondents who were employees of PT. Indotama. Data analysis in this study used an alternative method of structural equation modeling (SEM), namely partial least square (PLS). The first stage in this study was to test the validity of the questions for each variable along with its reliability. The second stage examines the factors that affect work productivity. The results of this study indicate that the variables of competence, job training and work discipline affect the performance of employees of PT. Indotama.
\end{abstract}

Keywords: Competence, Job Training, Work Discipline, Employee Performance

\section{Introduction}

Human Resources (HR) is the most expensive company asset compared to other assets because HR is the main driving force for a company organization. HR must be managed optimally, continuously and given extra attention and fulfill their rights, besides that HR is a partner of entrepreneurs to achieve organizational goals. Apart from companies, human resources must also improve their competence, in line with the development of the globalization era. To be able to compete, every company is required to have quality human resources.

Human resources play an important role in an organization to achieve its goals. The role of human resources is defined as a form of maximum ability in carrying out the tasks assigned by the organization in accordance with its main tasks and functions which include all activities in the organization, starting from planning, organizing, implementing activities to evaluating the results of activities.

Performance is the implementation of a job and the improvement of the work in accordance with its responsibilities so that it can achieve results as expected, Sinambela[1].

Improved employee performance will bring progress for the company to survive in an unstable business environment competition. Therefore, efforts to improve employee performance are the most serious management challenges because the success in achieving the goals and survival of the company depends on the quality of the performance of human resources in it. To support and improve employee performance, an employee must have competence. By having good competence, employees can achieve the results expected by the company. To achieve good competence requires training for employees to increase knowledge and increase the competencies that employees have for the success of an organization in the future. The work discipline of employees also has a very important role in achieving company development goals. Because 
discipline a job will ensure order and smoothness in duty to achieve optimal results. PT. Indomika Utama is engaged in production, of course, it must have a good performance. In addition to good performance, you must have good competence to achieve common goals, if you have good competence, training is needed to hone good competencies, and must be disciplined, because if you are not disciplined, employee performance will decrease and not achieve optimal results. PT. Indomika Utama is engaged in specialist acrylic services with quality and affordable prices. Also, PT. Indomika Utama accepts Media Advertise work with the best Advertising materials.

PT. Indomika Utama strives to provide the best service to consumers by applying the principle of "Acrylic Solution", namely by providing services ranging from concepts, designs, and dummy applications of various designs made from acrylics such as Acrylic Keychains, Acrylic Product Display, Plaques, Signs and Pass Cards.

The phenomenon in this study is that the overall work productivity is not achieved due to various problems, especially internally, including uneven employee competence resulting in gaps between employees, for example, if there is damage to the machine and people who normally handle the machine do not come to work, then the production process will be hampered because the person assigned to replace the absent employee is not as skilled as the employee. Also, the target time given is very short and there is a lack of training related to hard competencies.

According to researchers, training is very important, because to achieve the desired competence, one of them is through training because the competency levels and abilities of employees are different and it must be properly honed. When conducting training, employees can work together and if there are employees who are unable to attend or are moved to another department, then other employees will be replaced by employees who have the same abilities.

\section{Literature Review}

\subsection{Employee performance}

A company certainly wants to grow and develop the company itself. For that, a company needs to evaluate and evaluate its employees. Performance is a tangible behavior that is displayed by everyone as work performance produced by employees following their role in the company.

According to Mangkunegara, in Wibowo [2] Performance is the result of work in quality and quantity achieved by an employee in carrying out his duties by the responsibilities assigned to him.

According to Hasibuan, in Yani [3]Performance is a result of work achieved by a person in carrying out the tasks assigned to him based on skills, experience, and sincerity as well as time.

Thus it can be concluded that performance is a result where a person or group does something of the authority and responsibility that the company has given to its employees during the expected period to be able to provide and improve work performance that is better in its sincerity.

\subsection{Job competence}

Within the company, of course, wants employees to have good competence. Competence refers to the knowledge, skills, abilities, or individual personality characteristics of a person that directly affects a person's performance.

According to Hasibuan[4], competence is the knowledge, skills, and attitudes needed in carrying out their job duties which can be linked to increasing individual or team performance. According to MC Achsan in Sutrisno [5] competence is defined as knowledge, skills, and abilities that are controlled by someone who has become a part of himself, so that he can perform cognitive, affective, and psychometric behaviors as well as possible. If competence is an ability, it 
can be defined as the ability to work well, discipline, and know the rules that exist within the organization.

This explains that competence is a basic characteristic of a person that indicates how to think, behave, and act and draw conclusions that can be acknowledged and maintained by a person at a certain time. From these basic characteristics, it can be seen that the research objectives of the level of competence or competency standards can determine the level of expected performance and categorize the level as high or below average.

\subsection{Work training}

According to Simamora, in Widodo [6] training is a series of activities designed to increase skills, knowledge, experience, or changes in an individual's attitude.

According to Sjafri Mangkuprawira, in Yani [3]training is a process of teaching certain knowledge and skills as well as skills so that employees are more skilled and able to carry out their responsibilities better, according to standards.

According to Kasmir [7] training is a process to shape and equip employees by adding to their skills, abilities, knowledge, and behavior.

According to Bangun [8] training is a process of improving employee job skills to help achieve company goals. In general, training will be useful for improving employee work results and the more skilled employees will reduce the costs of their work.

Thus training is shaping employee behavior in accordance with what the company expects and employees are equipped with various knowledge, abilities, and expertise, according to their field of work.

\subsection{Work Discipline}

Discipline in the company is part of what is officially regulated, where the company will issue regulations in the form of company regulations. The measure of the success or failure of discipline in the company is when most of the rules are obeyed by most of the employees.

According to Latainer in Sutrisno [5], defines discipline as a force that develops in the body of employees and causes employees to voluntarily adjust to decisions, regulations, and high values of work and behavior.

According to Hasibuan [4], stating "discipline is the most important operational function of human resource management because the better the employee discipline, the higher work performance they can achieve. Without good employee discipline, it is difficult for company organizations to achieve optimal results. "

According to Dessler [9], Discipline is the awareness and willingness of a person to obey one's rules, all company regulations and social norms that apply awareness is if someone voluntarily obeys all the rules and is aware of duties and responsibilities.

\subsection{Work training}

According to Simamora, in Widodo [6] training is a series of activities designed to increase skills, knowledge, experience, or changes in an individual's attitude.

According to Sjafri Mangkuprawira, in Yani [3] training is a process of teaching certain knowledge and skills as well as skills so that employees are more skilled and able to carry out their responsibilities better, according to standards.

According to Kasmir [7] training is a process to shape and equip employees by adding to their skills, abilities, knowledge, and behavior.

According to Bangun [8] training is a process of improving employee job skills to help achieve company goals. In general, training will be useful for improving employee work results and the more skilled employees will reduce the costs of their work. 
Thus training is shaping employee behavior in accordance with what the company expects and employees are equipped with various knowledge, abilities, and expertise, according to their field of work.

\subsection{Work Discipline}

Discipline in the company is part of what is officially regulated, where the company will issue regulations in the form of company regulations. The measure of the success or failure of discipline in the company is when most of the rules are obeyed by most of the employees.

According to Latainer in Sutrisno [5], defines discipline as a force that develops in the body of employees and causes employees to voluntarily adjust to decisions, regulations, and high values of work and behavior.

According to Hasibuan [4], stating "discipline is the most important operational function of human resource management because the better the employee discipline, the higher work performance they can achieve. Without good employee discipline, it is difficult for company organizations to achieve optimal results. "

According to Dessler [9], Discipline is the awareness and willingness of a person to obey one's rules, all company regulations and social norms that apply awareness is if someone voluntarily obeys all the rules and is aware of duties and responsibilities.

\section{Hypothesis}

According to Hasibuan [4], competence is the knowledge, skills, and attitudes needed in carrying out their job duties which can be linked to increasing individual or team performance.

Research results from Saputra, Bagia and Suwendra [10], Budiman, Saerang and Sendow [11], Fadhil [12], Rohman [13] shows that competence has a significant influence on employee performance, besides that there is a research journal from Ratnasari [14] on competency variables which shows that there is no significant effect on employee performance. From the opinion of experts and previous studies, it can be concluded that there are a close relationship and influence between the competency factor and the employee performance factor. So, the relationship between the variables is:

H1: Competence has a positive effect on employee performance.

According to Kasmir [7] training is a process to shape and equip employees by adding to their skills, abilities, knowledge, and behavior. According to Bangun [8] training is a process of improving employee job skills to help achieve company goals. In general, training will be useful for improving employee work results and the more skilled employees will reduce the costs of their work. Research results from Safitri [15], Dubihlela and Rundora [16], Uzma and Waqar [17]. It shows that Job Training has a significant influence on Employee Performance. From the opinion of experts and previous studies, it can be concluded that there is a close relationship and influence between Job Training factors and Employee Performance factors. So, the relationship between the variables is:

$\mathrm{H} 2$ : Job training has a positive effect on employee performance.

According to Hasibuan [4], stating "discipline is the most important operational function of human resource management because the better the employee discipline, the higher work performance they can achieve. Without good employee discipline, it is difficult for company organizations to achieve optimal results. " Research results from Budiman, Saerang and Sendow[11], Meriam and Mentari, Fitriasari [18]. shows that work discipline has a significant effect on employee performance. From the opinion of experts and previous studies, it can be concluded that there are a close relationship and influence between work discipline and employee performance factors. So, the relationship between the variables is

H3: Work Discipline has a positive effect on Employee Performance. 


\section{Methods}

Designs and samples The design of this research is causal research which aims to test the hypothesis about the influence of the independent variables (Competence, Job Training, and Work Discipline) on the dependent variable (Employee Performance) at PT. Main Indomika. In this case, the study aims to determine the effect of competence, job training, and work discipline on employee performance at PT. Main Indomika. According to Sugiyono [19], the population is a generalization area consisting of: objects/subjects that have certain qualities and characteristics that are determined by the researcher to be studied and then draw conclusions. The number of population in PT. Indomika Utama has a total of 62 employees. According to Sugiyono[19], saturated sample is a sampling technique by taking all members of the population as respondents or samples. So this study uses a sample of 62 respondents who are employees or saturated sample research, namely taking the entire population as a sample because the number of available populations is not much. Analytical instruments and techniques

In this study, the authors use the basic measurement of performance variables adopted from Mangkunegara [20], while for competency variables adopted from Hasibuan [4], training variables are adopted from Simamora [21] and work discipline is adopted from Rivai [22].

\section{Results And Discussion}

Hypothesis Testing Results This hypothesis testing stage is carried out after the structural model evaluation stage is carried out. This stage is carried out to determine whether the research hypothesis proposed in the research model is accepted or rejected. To test the proposed hypothesis, it can be seen from the original sample and the T-Statistic value through the bootstrapping procedure. According to Helm et alin Hair et al.[23], the path coefficient values are in the range of values -1 to +1 , where the path coefficient values that are close to +1 represent a strong positive relationship and the path coefficient values that are -1 indicate a strong negative relationship. Meanwhile, the t-statistical value limit for rejecting and accepting the proposed hypothesis is \pm 1.96 , which is if the t-statistic value is in the range of -1.96 and 1.96 then the hypothesis will be rejected or in other words accept the null hypothesis (H0).

Table 1. Hypothesis Testing Results

\begin{tabular}{lccccc}
\hline Variabel & $\begin{array}{c}\text { Original } \\
\text { Sample } \\
(\mathbf{O})\end{array}$ & $\begin{array}{c}\text { Sample } \\
\text { Mean } \\
(\mathbf{M})\end{array}$ & $\begin{array}{c}\text { Standard } \\
\text { Deviation } \\
\text { (STDEV) }\end{array}$ & $\begin{array}{c}\text { T Statistics } \\
(\mid \mathbf{O} / \text { STDEV|) }\end{array}$ & $\begin{array}{c}\text { P- } \\
\text { Values }\end{array}$ \\
\hline $\begin{array}{l}\text { X1 (Competence) -> Y } \\
\text { (employee performance) }\end{array}$ & 0.134 & 0.138 & 0.112 & 1.200 & 0.230 \\
$\begin{array}{l}\text { X2 (training) -> Y (employee } \\
\text { performance) }\end{array}$ & 0.224 & 0.231 & 0.113 & 1.991 & 0.047 \\
$\begin{array}{l}\text { X3 (work dicipline) -> Y } \\
\text { (employee performance) }\end{array}$ & 0.591 & 0.599 & 0.082 & 7.218 & 0.000 \\
\hline \multicolumn{1}{c}{ Source- Smart PLS output (2020) }
\end{tabular}

Source: Smart PLS output (2020)

This study aims to determine the effect of competence, job training, and work discipline on employee performance at PT. Indomika Utama in the production section. The exogenous variables assessed in this research model are competence, job training, and work discipline. While the 
endogenous variable assessed in this research model is employee performance. Data analysis has been carried out from the conceptualization stage of the model to testing the research hypothesis. The results of the analysis can show whether exogenous variables can affect the endogenous variables of employee performance at PT. Indomika Utama Production section. The results of hypothesis testing indicate that of the total three hypotheses tested, two hypotheses are accepted and one hypothesis is rejected.

Based on the test results on the effect of competence on employee performance, the original sample value is 0.134 which is close to the value of +1 and has a T-Statistic value of $1.200(<1.96)$ so that it can be concluded that the first hypothesis (H1) is rejected and competence has no effect on employee performance. This is in line with the results of research conducted by Ratnasari [14] where competence does not affect employee performance.

Based on the test results on the effect of job training on employee performance, it has an original sample value of 0.224 which is close to the value of +1 and has a T-Statistic value of 1.991 (> 1.96) so that it can be concluded that the second hypothesis (H2) is accepted and job training has a positive and significant effect on performance. employees. Employee performance will increase if employees receive sufficient training so that they can develop the ability to improve their jobs. This is in line with the results of research conducted by Safitri [15] where Job Training has a positive and significant effect on Employee Performance.

Based on the test results on the effect of work discipline on employee performance, it has an original sample value of 0.591 which is close to the value of +1 and has a T-Statistic value of 7,218 (> 1.96) so that it can be concluded that the third hypothesis (H3) is accepted and work discipline has a positive and significant effect on performance. employee. With high work discipline, employee performance will increase. This is in line with the research results conducted by Saputra, Bagia and Suwendra [10] where Work Discipline has a positive and significant effect on Employee Performance.

\section{Conclusion and Suggestion}

Based on the results of hypothesis testing and the discussion started in the previous chapter, several conclusions can be obtained as follows:

1. Competence has no effect on employee performance. This means that employees have a good level of competence in supporting employee performance at PT. Main Indomika.

2. Job training affects employee performance. This means that there must be improvements and improvements to employee job training in order to be able to improve employee performance owned by employees at PT. Main Indomika.

3. Work Discipline has a significant effect on Employee Performance. This means that there must be improvements and improvements in employee Work Discipline in order to be able to improve the Employee Performance of the Employees at PT. Main Indomika.

Suggestion. Based on the results of the research conducted, the researchers gave several suggestions because this study still has several limitations from several aspects so that it is necessary to make improvements in further research, as follows:

1. For Competency Variables, The competency variable that has the lowest mean value in the KO3 statement is "I have work experience in the current field of work" which means that the respondent does not quite agree that the respondent has work experience in the current line of work. This confirms that not all employees of PT. Indomika Utama the Production section who feels they have work experience in the current field of work. Suggestions for improving the management of PT. Indomika Utama in the Production section is paying more attention to the competence of each production employee so that they have overall experience and abilities 
2. For Job Training Variables The job training variable which has the lowest mean value in the PL8 statement is "The training provided can improve my ability to communicate with other employees" which means that the respondents do not quite agree that the training provided can improve the respondent's ability to communicate with other employees. This confirms that there are still employees of PT. Indomika Utama, the production division, believes that the training provided has not been able to improve the ability of respondents to communicate with other employees. Suggestions for the management of PT. Indomika Utama in the Production section in order to provide comprehensive job training for employees in order to be able to further improve employee communication skills.

3. Work Discipline Variable The work discipline variable that has the lowest mean value in the DK10 statement is "Employees have good ethics while in the office" which means that respondents do not quite agree that employees have good ethics while in the office. This confirms that not all employees of PT. Indomika Utama is part of the production with good ethics while in the office. Suggestions for the management of PT. Indomika Utama, the Production section, to tighten company SOPs so that it is hoped that ethical work discipline will be created at all levels of employees.

4. For Employee Performance Variables The employee performance variable that has the lowest mean value in the KK1 statement is "So far I always come to work earlier than the predetermined time". This confirms that not all employees of PT. Indomika Utama Production section in carrying out work always comes to the workplace earlier than the predetermined time. Suggestions for the management of PT. Indomika Utama is in the Production section in order to make the culture come early so that the culture is cultured in the company's work environment.

\section{Reference}

[1] L. Sinambela, Kinerja Pegawai: Teori, Pengukuran dan Implikasi. Yogyakarta: Graha Ilmu, 2012.

[2] WIbowo, Manajemen Kinerja. Jakarta: Rajawali Pers, 2013.

[3] Y. H.M., Sumber Daya Manusia. Jakarta: Mitra Wacana Media, 2012.

[4] H. Malayu, Manajemen Sumber Daya Manusia. Jakarta: Bumi Aksara, 2012.

[5] S. Edy, Manajemen Sumber Daya Manusia. Jakarta: Kencana, 2010.

[6] W. S. Eko, Manajemen Pengembangan Sumber Daya Manusia. Yogyakarta: Pustaka Pelajar, 2015.

[7] Kasmir, Manajemen Sumber Daya Manusia (Teori dan Praktek). PT. Raja Grafindo Persada, 2016.

[8] Bangun Wilson, Manajemen Sumber Daya Manusia. Jakarta: Erlangga, 2012.

[9] G. Dessler, Manajemen Sumber Daya Manusia. Jakarta: Gramedia, 2010.

[10] U. R. Amalia, I. W. Suwendra, and I. W. Bagia, "Kinerja Karyawan,” vol. 4, no. 1, pp. 121-130, 2016.

[11] N. P. Budiman, I. S. Searang, and G. M. Sendow, "Pengaruh Kompetensi, Motivasi, Dan Disiplin Kerja Terhadap Kinerja Karyawan (Studi Pada Pt. Hasjrat Abadi Tendean Manado)," J. Chem. Inf. Model., vol. 53, no. 9, pp. 1689-1699, 2019, doi: 10.1017/CBO9781107415324.004.

[12] M. Fadhil, "Pengaruh Kompetensi Sumber Daya Manusia Terhadap Kinerja Pegawai Pada Balai Latihan Kerja Industri Makassar," vol. 01, pp. 2355-538, 2016.

[13] F. Rohman, "Kompetensi Sdm Dan Pengaruhnya Terhadap Kinerja Karyawan Bagian Akuntansi Ksp Di Kabupaten Jepara,” Jeam, vol. XV, no. 20, pp. 62-67, 2016, doi: 10.19184/jeam.v15i1.1796.

[14] S. L. Ratnasari, "Pengaruh Kompetensi Dan Kompensasi Terhadap Kinerja Karyawan Departemen Quality Assurance Pt. Peb Batam,” Pros. Semin. Nas. Ekon. dan Bisnis, no. 1, pp. 424-434, 2016.

[15] D. E. Safitri, "PENGARUH PELATIHAN TERHADAP KINERJA KARYAWAN THE EFFECT OF TRAINING ON EMPLOYEE PERFORMANCE Debby Endayani Safitri," Dimens. Vol. 8, vol. 8, no. 2, pp. 240-248, 2019.

[16] J. Dubihlela and R. Rundora, "Of Activity Based Costing; Impact On Performance Of SMEs," Int. Bus. Econ. Res. J., vol. 13, no. 1, pp. 27-39, 2014. 
[17] U. Hafeez and W. Akbar, “'Impact of Training on Employees Performance' (Evidence from Pharmaceutical Companies in Karachi, Pakistan)," Bus. Manag. Strateg., vol. 6, no. 1, p. 49, 2015, doi: 10.5296/bms.v6i1.7804.

[18] M. Fitriasari, A. T. Haryono, and M. M. Warso, "Analysis the Influence of Compensation Work, Discipline Work, And Workplace Physical Of The Performance Of Employees With Work Performance As Variable Interveningnya ( Study In Pt. Mandiri Karya Perdana),” J. Manage., vol. 02, no. 02, 2016.

[19] Sugiyono, Statistika Untuk Penelitian. Bandung: Alfabeta, 2013.

[20] A. P. Mangkunegara, Manajemen Sumber daya Manusia Perusahaan. Bandung: PT. Remaja Rosdakarya, 2011.

[21] H. Simamora, Manajemen Sumber Daya Manusia. Yogyakarta: Bagian Penerbitan Sekolah Tinggi Ilmu Ekonomi YKPN.

[22] V. Rivai, Manajemen Sumber Daya Manusia untuk Perusahaan. Jakarta: Raja Grafindo Persada, 2008.

[23] J. F. Hair, M. Sarstedt, L. Hopkins, and V. G. Kuppelwieser, "Partial least squares structural equation modeling (PLS-SEM): An emerging tool in business research," Eur. Bus. Rev., vol. 26, no. 2, pp. 106-121, 2014, doi: 10.1108/EBR-10-2013-0128. 